\title{
of the Nutrition
}

\section{Society}

VOLUME 50 NUMBER 3 DECEMBER 1991 


\title{
EDITED FOR THE NUTRITION SOCIETY
}

\author{
J. C. MATHERS \\ Proceedings of the English Group \\ J. QUARTERMAN \\ Proceedings of the Scottish Group \\ D. A. T. SOUTHGATE \\ Chairman of the Editorial Board
}

The Nutrition Society has as its object the advancement of the scientific study of nutrition and its application to the maintenance of human and animal health.

Application for membership is invited from anyone whose work has contributed to the scientific knowledge of nutrition, whether such work has been in the laboratory, the field or the clinic, and whether experimental, clinical, agricultural or statistical in nature. There is also a student membership scheme with reduced subscriptions.

Particulars of The Nutrition Society and application forms for membership may be had from the Honorary Secretary, Dr. R. F. Grimble, The Nutrition Society, 10 Cambridge Court, 210 Shepherds Bush Road, London W6 7NJ.

The Proceedings of The Nutrition Society, published by the Cambridge University Press, in part, record meetings of the Symposium type, at which experts in a particular field are invited by Council to make contributions on specific parts thereof and at which general discussion follows these invited contributions. The contributions will be published in extenso: such summaries of the ensuing discussion as circumstances warrant may also be published. The Society also holds scientific meetings at which papers are communicated by members and others on original work carried out by them. It is proposed at present to publish summaries of the papers read at each meeting, each communication being recorded in the Society's Proceedings by means of an abstract not exceeding in length 400 words or the equivalent space in print. The Proceedings are published three times a year.

The British Journal of Nutrition is published by Cambridge University Press for The Nutrition Society, which owns it and controls its publication. It is devoted to reports of original work in all branches of nutrition, the term 'original work' not implying that the papers must invariably be based on new facts. The British Journal of Nutrition does not print reviews of the literature or polemical articles, but the Editorial Board is willing to consider original articles critically re-examining published information and the conclusions drawn from it. A volume consists of three parts: two volumes are published each year. For 1991, the annual Nutrition Research Reviews is included as a supplement.

Subscriptions to the Society's Publications. For non-members of the Nutrition Society the subscription including postage to Volume 50, 1991 of the Proceedings, is $£ 90$ in UK, $£ 93$ elsewhere, payable in advance to the Cambridge University Press, The Edinburgh Building, Shaftesbury Road. Cambridge CB2 2RU or to any bookseller. The subscription in USA and Canada is US \$190 and enquiries should be addressed to the Cambridge University Press, Journals Department, 40 West 20th Street, New York, NY 10011-4211. All orders must be accompanied by payment.

The annual subscription to the Journal, including Nutrition Research Reviews, is $£ 205$ in UK. $£ 210$ elsewhere (US $\$ 419$ in the USA and Canada).

The price for single issues of the Journal is $£ 31$ (USA and Canada \$69). Single issues of the Proceedings are $£ 31$ net (USA and Canada \$69), postage extra.

POSTMASTER: send address changes in USA and Canada to Proceedings of the Nutrition Society, Cambridge University Press, 110 Midland Avenue, Port Chester, New York, NY 10573-9864.

A claim for the replacement of a publication lost in transmission will not be entertained unless made immediately upon receipt of the subsequent issue.

(C) The Nutrition Society, 1991.

Copying. This journal is registered with the Copyright Clearance Center, 27 Congress St., Salem, Mass. 01970. Organizations in the USA who are also registered with C.C.C. may therefore copy material (beyond the limits permitted by sections 107 and 108 of US Copyright law) subject to payment to C.C.C. of the per-copy fee of \$5. This consent does not extend to multiple copying for promotional or commercial purposes. Code 0029-6651/91/4900-4900\$5.

ISI Tear Sheet Service, 3501 Market Street, Philadelphia, Pennsylvania 19104, USA, is authorized to supply single copies of separate articles for private use only.

For all other use, permission should be sought from the Cambridge or American Branch of 